\title{
Algumas relações intertextuais entre Euclides da Cunha e Guimarães Rosa
}

\author{
Alfredo Cesar-Melo ${ }^{1}$
}

\section{Resumo}

A relação entre as principais obras de Euclides da Cunha e Guimarães Rosa tem chamado a atenção da crítica literária, com ênfase para as semelhanças estruturais; a maneira como o ensaio de Euclides ilumina o contexto do romance de Rosa; ou, até mesmo, a forma como Guimarães reescreve $O$ s sertões. Neste artigo, empreendo uma análise centrada na diferença entre o gênero ensaístico e romanesco, destacando como Guimarães Rosa utiliza a ficção para desenvolver certas intuições euclidianas. Estudo um tipo de relação entre literatura e sociedade que não se fia exclusivamente na identidade entre estruturas sociais e literárias, mas exatamente na sua não identidade, isto é, na capacidade da ficção rosiana de vislumbrar virtualidades e imaginar alternativas para as estruturas sociais vigentes. Três temas euclidianos tratados em Grande sertão: veredas serão evidenciados neste ensaio: o exílio; o conflito entre a civilização e a barbárie; e a transfiguração do sertanejo.

\section{Palavras-chave}

Intertextualidade, Guimarães Rosa, Euclides da Cunha, sertão

Recebido em 18 de setembro de 2010

Aprovado em 6 de junho de 2011

1 Doutor em Literatura Hispânica pela Universidade da Califórnia, em Berkeley. Professor de literaturas e culturas lusófonas na Universidade de Chicago, Estados Unidos. E-mail: alfmelo@gmail.com 


\title{
Some textual relationships between Euclides da Cunha and Guimarães Rosa
}

\author{
Alfredo Cesar-Melo
}

\begin{abstract}
Many literary critics have studied the relationship between the great works by Euclides da Cunha and Guimarães Rosa, emphasizing their structural similarities; the way Euclides da Cunha's essay sheds light on Grande Sertão: Vereda's context; and how Rosa rewrites ideologically Os Sertões. In this article my analysis centers on the difference between the essayistic genre and the novel, highlighting the way Rosa makes use of fictional discourse in order to put forward certain Euclide da Cunha's intuitions. The kind of interplay between literature and society I want to discuss in this article does not rely exclusively on the identity between social structures and literary discourse. I want grasp exactly the opposite: the non-identity between these two terms, i.e., the power of Rosa's fiction to imagine alternative worlds to the current social structures. I deal with three themes put forward by Euclides da Cunha which are developed by Rosa: the exile, the conflict between Civilization and Barbarism and the theme of transfiguration.
\end{abstract}

\section{Keywords}

Intertextuality, Guimarães Rosa, Euclides da Cunha, Brazilian backlands. 


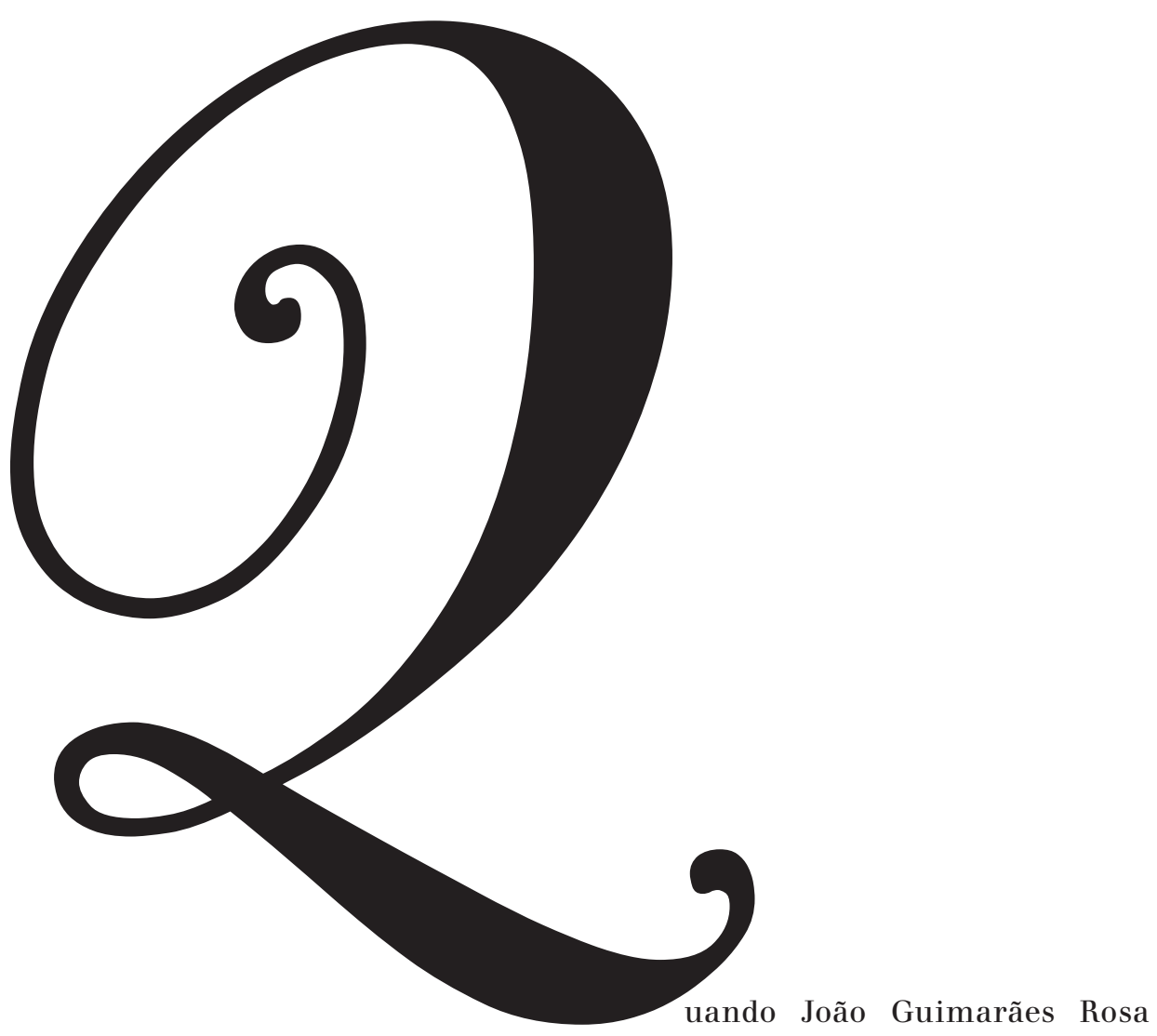

publicou Grande sertão: veredas, em 1956, escrever sobre o sertão não era apenas um convite perigoso para resvalar no pitoresco, mas também implicava navegar por mares muito antes já navegados por uma sólida tradição literária brasileira, representada por José de Alencar, Franklin Távora, Afonso Arinos e, sobretudo, Euclides da Cunha. Esses escritores fizeram do sertão um tópos da literatura brasileira: mobilizaram arsenais retóricos dos mais diversos (da ciência à mitologia grega) para criar certas representações que se cristalizaram no imaginário nacional. Todavia, nenhum deles foi mais eloquente e exerceu maior impacto na vida literária e cívica do Brasil do que Euclides da Cunha. Foi o autor de Os sertões o artífice do discurso que insere o sertanejo no centro da nacionalidade e que interpela o brasileiro letrado da urbe a conhecê-lo e valorizá-lo. Escrever sobre o sertão depois de Os sertões não deixava de transparecer um desejo, por parte do letrado brasileiro, de medir-se, de algum modo, com Euclides da Cunha ${ }^{2}$.

2 Em seu A imitação dos sentidos, Leopoldo Bernucci estuda as relações literárias de Euclides da Cunha com outros escritores dessa tradição literária que têm o sertão como referente: José de Alencar e Afonso Arinos, além de investigar o impacto do texto euclidiano em escritores de outras gerações, caso de Monteiro Lobato e Graci- 
Portanto, é perfeitamente compreensível que se busque elos entre um dos romances mais importantes do século XX no Brasil e um dos ensaios de interpretação nacional mais canônicos da cultura brasileira, afinal, tais narrativas-chave lidam com o mesmo referente: o sertão e os sertanejos brasileiros. Foi Antonio Candido, em seu artigo "O homem dos avessos", quem primeiro sugeriu os paralelos entre as obras de Euclides e Guimarães Rosa, salientando que Grande sertão: veredas, ao seu modo, também era uma narrativa sobre a Terra, o Homem e a Luta do sertão ${ }^{5}$. Walnice Galvão, por sua vez, utiliza-se de Euclides da Cunha, no seu estudo As formas do falso, para iluminar o contexto sócio-histórico do romance de Guimarães Rosa ${ }^{4}$. Muitos anos depois, a sugestão esboçada por Candido foi aceita e desenvolvida, de forma radical, por Willi Bolle, no seu livro grandesertão.br. Esse estudioso afirma que Grande sertão: veredas é uma reescritura de $O s$ sertões ${ }^{5}$. Ainda mais: que o romance de

liano Ramos. Embora seja o estudo mais completo sobre a rede intertextual criada em torno a Euclides da Cunha, isto é, a relação que a obra de Euclides da Cunha estabeleceu com seus prógonos, contemporâneos e epígonos, Guimarães Rosa é uma grande lacuna no estudo de Bernucci. Ver BERNUCCI, Leopoldo. A imitação dos sentidos: prógonos, contemporâneos e epígonos de Euclides da Cunha. São Paulo: Edusp, 1995 .

3 CANDIDO, Antonio. O homem dos avessos. In: COUTINHO, Eduardo (Org). Guimarães Rosa: Coleção Fortuna Crítica. Rio de Janeiro: Civilização Brasileira, 1983.

4. GALVÃO, Walnice. As formas do falso. São Paulo: Nova Perspectiva, 1972. É sintomático que, no decorrer da pesquisa para sua tese de doutoramento sobre Grande sertão: veredas, Walnice Galvão tenha se interessado tanto por Euclides da Cunha a ponto de se tornar uma das maiores especialistas em sua obra. Galvão explica: "Verificando que as marcas de Os sertões eram visíveis em Grande sertão: veredas, sobre o qual versara meu doutorado, pareceu-me passo lógico estudar Euclides da Cunha. Aproximavam os dois escritores o amplo espaço que escolheram para cenário de seus livros, as entranhas do país; os homens que nele vivem, jagunços ou cangaceiros; o estado de guerra; e as galas do verbo. Ambos são elaboradores de linguagem, praticantes interessados de processos lexicogênicos, versados em sintaxes arrevesadas e com pendor para arcaísmos, embora de modos diferentes" (GALVÃO, Walnice. Euclidiana: ensaios sobre Euclides da Cunha. São Paulo: Companhia das Letras, 2oog. p. 6.)

5 Compartilho com Willi Bolle a crença de que passamos a compreender melhor Grande sertão: veredas quando o comparamos com Os sertões, de Euclides da Cunha. Discordo apenas da maneira como Bolle compara as duas obras. Dissertando sobre as relações intertextuais entre o romance de Mario Vargas-Llosa, La guerra del fin del mundo, e o ensaio euclidiano, Efraín Kristal afirma que não é preciso haver conhecimento prévio de Os sertões para entender a ficção de Vargas-Llosa (KRISTAL, Efraín. The Temptation of the Word: The Novels of Mario Vargas Llosa. Nashville: Vanderbilt University Press, 1998. p. 127). Da mesma maneira como não é preciso conhecer teologia medieval para entender a Divina comédia de Dante, nem é necessário ler “Dos Canibais”, de Montaigne, para apreciar a peça $A$ tempestade, escrita por Shakespeare; o que não impede de registrarmos um ganho crítico considerável quando somos capazes de encontrar 
Rosa faria parte do conhecido gênero dos "retratos do Brasil", estando em companhia de Casa-grande \& senzala, de Gilberto Freyre; Raizes do Brasil, de Sérgio Buarque de Holanda; Retrato do Brasil, de Paulo Prado; e do próprio Os sertões, de Euclides da Cunha.

De acordo com Bolle, "Grande sertão: veredas pode ser lido como um processo aberto contra o modo como o autor de Os Sertões escreve a história". Enquanto o ensaio euclidiano forneceria uma "visão de cima" da sociedade brasileira ${ }^{7}$, o texto rosiano mostraria uma perspectiva dos de baixo. O narrador-cientista de Os sertões se apresenta como um "narrador sincero", confiante na verdade que sua ciência positivista é capaz de descobrir; enquanto Riobaldo - a voz narrativa que organiza o entrecho romanesco de Grande sertão: veredas - conta sua vida num tom dubidativo. Embora Bolle interprete o romance de Guimarães Rosa como uma reescritura de Os sertões, parece claro que há, em seu argumento, uma nítida preferência pela ficção rosiana, em detrimento do ensaio euclidiano, como se a primeira, ao final, nos mostrasse um retrato do Brasil mais complexo, nuançado e popular do que o segundo.

Trata-se de uma avaliação problemática, já que estamos diante de obras tão apartadas no tempo. As mudanças ocorridas entre 1902 e 1956, nos âmbitos literário, estilístico, ideológico, político, sócio-histórico, são tantas que qualquer cotejo direto entre duas obras separadas por essas datas pode facilmente recair numa análise anacrônica e sem 0 devido senso de mediação. Tal juízo de Bolle, no entanto, é o corolário de uma estratégia de leitura: entender Grande sertão: veredas como um retrato do Brasil. Ao ligar o romance de Guimarães Rosa e o ensaio histórico-sociológico de Euclides da Cunha, compreendendo-os como textos pertencentes ao mesmo gênero, Bolle passa a tratar as duas obras como se fossem cognitivamente comparáveis; o que pode, em tese, tornar um retrato do Brasil mais agudo e perspicaz que o outro. É essa a impressão deixada pela leitura de grandesertão.br: a de que Guimarães Rosa interpretou o Brasil com mais acuidade sociológica e fineza analítica do que Euclides da Cunha.

Creio que o estudo sobre as relações intertextuais entre Os sertões e Grande sertão: veredas pode ganhar outro entendimento quando passamos a valorizar exatamente a diferença de gênero literário entre os dois textos. Neste artigo, pretendo mostrar como Guimarães Rosa

ressonâncias significativas de um texto em outro, como é o caso - que espero mostrar - de Os sertões e Grande sertão: veredas.

6 BOLLE, Willi. grandesertão.br. São Paulo: Editora 34, 2004. p. 53.

7 Idem, ibidem, p. 35 . 
desenvolve certas intuições apresentadas em Os sertões, levando em conta as propriedades do discurso ficcional. É por se tratar de uma obra imaginativa que o romance de Rosa permite vislumbrar de maneira mais radical, por exemplo, outras configurações da relação entre civilização e barbárie e investigar as virtualidades desse rearranjo. É justamente esse desdobramento ficcional das intuições contidas em $O s$ Sertões que pretendo discutir.

Na resenha que escreveu sobre grandesertão.br, Luiz Costa Lima censura a dimensão documental da hipótese levantada por Bolle ${ }^{8}$ - e que, segundo ele, era hegemônica ainda em boa parte da crítica literária de orientação sociológica no Brasil. Neste artigo, pretendo empreender uma análise centrada na relação entre literatura e sociedade que não se fia exclusivamente na identidade entre estruturas sociais e literárias, mas exatamente na sua não identidade, isto é, na capacidade da literatura de vislumbrar virtualidades e imaginar alternativas para as estruturas sociais vigentes.

Darei ênfase para três temas euclidianos que são trabalhados em Grande sertão: veredas: os temas do exílio; do conflito entre a civilização e a barbárie; e da transfiguração do sertanejo.

\section{Exílio}

Um dos grandes temas de Os sertões é a separação entre os brasileiros do litoral e do sertão. É como se esses dois segmentos da população fossem exilados um em relação ao outro. Eram, no dizer de Euclides da Cunha, "duas sociedades, de todo alheias uma à outra" ${ }^{9}$. Os brasileiros do litoral viviam exilados do cimento orgânico da nacionalidade - os sertanejos -; enquanto estes últimos estavam isolados dos melhoramentos técnicos e intelectuais trazidos pelo progresso. A nação vivia, assim, sob um sistema de alienações mútuas, isto é, um duplo exílio ${ }^{10}$.

Em Grande sertão: veredas, Guimarães Rosa consegue internalizar essa dupla perspectiva do exílio num só personagem, o narrador Riobaldo. Isso porque Riobaldo questiona tanto o mundo da tradição sertaneja de Joca Ramiro, quanto a crença cega no progresso citadino, empunhada por Zé Bebelo. Na primeira parte do romance, em vários

8 LIMA, Luiz Costa. Riobaldo: culpa e luta. Revista USP, São Paulo, n. 65, p. 193, 2005.

9 CUNHA, Euclides. Os sertões: campanha de Canudos. São Paulo: Ateliê, 2oo2. p. 26.

10 Para um estudo sistemático sobre a figura do exílio na literatura brasileira, inclusive no ensaio euclidiano, cf. ROCHA, João Cezar de Castro. O exílio do homem cordial: ensaios e revisões. Rio de Janeiro: Museu da República, 2005. 
momentos do seu relato Riobaldo mostra seu desconforto em relação às duas visões de mundo que pelejavam pelo controle do sertão. Trata-se de um personagem em crise e desenraizado, reticente em relação ao mundo que o cerca. Segundo Georg Lukács, o principal tema e matéria do romance moderno seria a percepção, cada vez maior, de que ao homem moderno falta uma morada ontológica ${ }^{11}$. Essa constatação do exílio existencial, enfrentado pelos homens na modernidade, seria a mola criadora do gênero romanesco nas suas manifestações mais recentes ${ }^{12}$. Guimarães Rosa se utiliza, portanto, de um dilema central do pensamento social brasileiro - narrativizado por Euclides da Cunha como a tragédia do duplo exílio - e funde esse sistema de alienações mútuas num único personagem, e, desse modo, imprime uma força reflexiva até então incomparável na ficção brasileira.

O exílio é um espaço para estranhamentos que, por sua vez, geram questionamentos, dúvidas e reflexões. O mal-estar de Riobaldo diante das práticas jagunças, sua desconfiança perante a louvação exagerada a Joca Ramiro e seu ceticismo para com o discurso modernizador de Zé Bebelo deixam-no numa posição que muito se afasta da representação habitual do sertanejo resignado na sua servidão, como esta levada a cabo pelo sociólogo fluminense Oliveira Vianna, ao afirmar que "o meio rural é, em toda parte, um admirável conformador de almas"13. Riobaldo é uma voz marcadamente inconformista, questionando os pressupostos de seu discurso, colocando em xeque suas próprias certezas. Embora ele tenha confessado que "sertão é o lugar onde o pensamento da gente se forma mais forte que o poder do

11 Davi Arrigucci também utiliza a teoria do romance de Georg Lukács para dar inteligibilidade aos dilemas de Riobaldo. Arrigucci interpreta o desterramento existencial de Riobaldo como uma condição que se torna gradativamente mais forte ao longo do romance (ARRIGUCCI, Davi. O mundo misturado: romance e experiência em Guimarães Rosa. Novos Estudos Cebrap, n. 40, p. 29, 1994). Eis o meu ponto de desacordo: a meu ver, na segunda metade do romance, Riobaldo tenta se encaixar na sociabilidade sertaneja, apesar dos inúmeros contratempos. Ao final da narrativa, ele encontra seu espaço no sistema jagunço. Em decorrência de sua vitória sobre Hermógenes, torna-se famoso e benquisto no sertão. Riobaldo herda a fazenda de seu padrinho e casa-se com Otacília, conciliando-se com a ordem social do sertão e passando a exercer um papel de prestígio. Não se pode dizer que o velho fazendeiro Riobaldo seja um desterrado existencial. Ainda que tenha dúvidas sobre muita coisa e remoa sua culpa, ele sabe qual é o seu lugar social e está ajustado na ordem estabelecida. Minhas observações se restringem sobretudo à primeira parte do romance, de um Riobaldo ainda cheio de incertezas em relação ao seu futuro e de seu lugar no sertão.

12 LUKÁCS, Georg. The Theory of the Novel. Trans. Anna Bostock. Cambridge: MIT, 1974. p. 35.

13 VIANNA, Oliveira. Populações meridionais do Brasil. Niterói: EDUFF, 1987. p. 4,8. 
lugar"14, queixando-se ao seu interlocutor letrado da falta de convívio instrutivo naquela região, será o próprio narrador que irá, no decorrer de seu relato, desconstruir ou relativizar "o pensamento da gente", isto é, as crenças coletivas da região. O motor-reflexivo do romance está no conflito entre alguém que se torna um individuo, com pensamento autônomo, numa ordem social onde não há espaço para o individuo. É esse conflito que explica a constante oscilação do personagem-narrador entre a estranheza e a identificação com o mundo do sertão.

Por ter participado desses dois grupos que lutam pelo destino do sertão (os "modernizadores" bebelos e os "tradicionalistas" ramiros), Riobaldo se sente muitas vezes dividido. Passou sua infância escutando as histórias de seu padrinho Selorico Mendes, que tanto enaltecia a coragem e os feitos dos joca-ramiros, capazes de "impor caráter ao governo"15. E quando foge da Fazendo São Gregório, acaba se tornando professor de Zé Bebelo, que o convida para integrar seu grupo. Mas ficou cansado "de se ir com tanta largueza, matando e prendendo gente na constante brutalidade"16, fugindo assim do bando de Zé Bebelo para depois integrar-se aos comandados por Joca Ramiro. Ainda assim, Riobaldo não deixa de ter empatia e afeição por Zé Bebelo. Em alguns momentos, sobretudo quando se depara com o espírito bárbaro e violento de Hermógenes, chega a afirmar que é Zé Bebelo quem tem a razão na guerra travada entre os dois grupos: "De repente, eu via que estava desejando que Zé Bebelo vencesse, porque era ele quem estava com a razão. Zé Bebelo devia de vir, forte viesse: liquidar mesmo, a rás, com o inferno da jagunçada!"17.

Quando estava no bando de Zé Bebelo, Riobaldo foi perguntado sobre os joca-ramiros e achou, num gesto de pressentimento, que, "se contasse, perfazia ato de traição"18. Por sua vez, quando fazia parte dos jagunços de Joca Ramiro, e foi questionado meticulosamente por Titão Passos sobre os métodos de batalha de Zé Bebelo, não se sentiu bem com a situação, temendo trair o seu antigo chefe. "Para melhor pensar, fui mal-respondendo, me calando, falando que era vasto. Como eu ia depor? Podia? Tudo o que eu mesmo quisesse. Mas, traição, não"19. Emparedado por essas duas forças, as da modernidade ("civilização")

14 ROSA, João Guimarães. Grande sertão: veredas. Rio de Janeiro: Nova Aguilar, 1994. p. 35 .

15 Idem, ibidem, p. 163.

16 Idem, ibidem, p. 135.

17 Idem, ibidem, p. 17 .

18 Idem, ibidem, p. 134.

19 Idem, ibidem, p. 150. 
e da tradição ("barbárie"), tentando de alguma forma conciliá-las ainda que consciente de que tal empreitada era difícil -, Riobaldo vive, nessa primeira guerra, uma crise de identidade. "Eu devia? Não devia? Vi vago o adiante da noite, com sombras mais apresentadas. Eu, quem é que eu era? De que lado eu era? Zé Bebelo ou Joca Ramiro? Titão Passos... o Reinaldo... De ninguém eu era. Eu era de mim. Eu, Riobaldo. Eu não queria contar" ${ }^{20}$.

Riobaldo vive na oscilação entre esses dois grupos, que representam coisas tão diferentes no que diz respeito à gestão do Norte e que, de certa forma, também traduzem o próprio dilaceramento interno do personagem diante da sociabilidade sertaneja, de se sentir pertencente e estranho àquele modo de vida, de identificar-se e questionar as regras daquela sociedade violenta e calcada num rígido código de honra. A fortuna crítica rosiana tem enfatizado bastante a metáfora do sertão como mundo. Mas pouco se tem estudado a subjetividade de Riobaldo como palco dos mesmos dilemas que o sertão enfrenta. Há uma relação de contiguidade e homologia entre essas duas dimensões: tal como o sertão, Riobaldo também estava, por meio de lutas, buscando um destino e pelejando com vetores ideológicos similares.

\section{Civilização e barbárie}

Outro tema em comum tratado por Guimarães Rosa e Euclides da Cunha seria o da luta entre civilização e barbárie no sertão brasileiro. Vimos como Guimarães Rosa transforma esse tópos do pensamento social latino-americano em mola para criação romanesca, uma vez que Riobaldo se digladia internamente, questionando as sociabilidades, ora advindas da modernidade (discurso civilizador), ora ligadas à tradição (denominada por Euclides como "barbárie" e "atavismo"). Tal internalização do conflito "civilização versus barbárie" faz de Riobaldo um personagem eminentemente moderno, uma vez que mostra seu desenraizamento, vivendo sem uma morada ontológica. Guimarães Rosa, entretanto, representa o conflito não apenas no âmbito interno do personagem-narrador, mas também no plano externo, encenando a luta entre os bebelos e os ramiros.

É importante salientar que tanto Euclides da Cunha quanto Guimarães Rosa lidam dialeticamente com a dicotomia "civilização versus barbárie”. Essa semelhança deve ser destacada, uma vez que

20 Idem, ibidem, p. 151. 
Willi Bolle, no seu grandesertão.br, contrapõe, um tanto esquematicamente, o enfoque de Guimarães Rosa ao de Euclides da Cunha sobre o mencionado tema: "No plano intertextual, ao encenar o conflito poder da cidade versus poder do sertão, Guimarães Rosa reconstrói em forma de paródia o padrão maniqueísta de Euclides que opõe a rua do Ouvidor às caatingas"21.

Uma leitura atenta de Os sertões evidencia que a análise de Euclides da Cunha não representa a relação entre a cidade e o sertão de modo maniqueísta. Por exemplo, Euclides mostra que os vaqueiros eram servos dos fazendeiros, e que estes, na verdade, viviam na cidade:

O fazendeiro do sertão vive no litoral, longe dos dilatados domínios que nunca viu, às vezes. Herdaram velho vício histórico. Como os opulentos sesmeiros da colônia usufruem, parasitariamente, as rendas das suas terras, sem divisas fixas. Os vaqueiros são-lhes servos submissos. ${ }^{22}$

Ao tratar da violência dos jagunços, característica associada à "barbárie" do sertão, Euclides da Cunha consegue vincular esse traço aparentemente arcaico às decisões políticas tomadas na urbe moderna, lembrando que os jagunços eram utilizados nas guerras dos chefes políticos: "A nossa civilização de empréstimo arregimentava, como sempre o fez, o banditismo sertanejo" ${ }^{23}$. Em Grande sertão: veredas, essas conexões também estão sugeridas, sobretudo na relação entre Joca Ramiro, líder maior dos jagunços, e Mirabô de Melo, chefe político cuja fazenda Sempre-Verde foi utilizada para realizar o julgamento de Zé Bebelo. Desnecessário dizer que no momento do julgamento, a fazenda estava vazia, o que é uma clara alusão à sistemática ausência dos chefes políticos no sertão. Trata-se da presença ausente da "civilização" na "barbárie" do sertão.

Parece claro tanto para Euclides da Cunha como para Guimarães Rosa que a civilização e a barbárie, a cidade e o sertão não estão separados por um abismo intransponível e maniqueísta. Pelo contrário, há uma articulação entre esses polos. Creio que esse é um ponto central do pensamento de Euclides da Cunha e que, de certo modo, também é desenvolvido por Guimarães Rosa.

21 BOLLE, Willi. op. cit., p. 136.

22 CUNHA, Euclides. op. cit., p. 217.

23 Idem, ibidem, p. 304. 
Segundo Luiz Roncari, Guimarães Rosa filiou-se a uma tradição intelectual - que tem como um dos seus representantes, o crítico Alceu Amoro Lima - que entendia o problema da civilização brasileira "como um problema de assimilação" ${ }^{24}$, já que o país era marcado por uma disparidade enorme de condições socioeconômicas, exemplificada por realidades tão distintas como as do Brasil do litoral e as do Brasil sertanejo. Faz parte da imaginação política brasileira pensar em maneiras de diminuir essas desigualdades e homogeneizar socialmente a nação.

Seria preciso, creio eu, nuançar essa caracterização de Roncari. Guimarães Rosa e Euclides da Cunha foram intelectuais bastante conscientes de que mais que um problema de assimilação entre diferentes grupos sociais e regiões do país, o problema da nação era se perguntar que tipo de assimilação o Brasil desejava para si, uma vez que cidade e sertão, modernidade e arcaísmo são constantemente articulados e entrelaçados na vida social brasileira. Em Os sertões, Euclides de Cunha denuncia a maneira como os sertanejos são explorados e utilizados como massa de manobra pelas elites citadinas e clama por um outro tipo de integração entre cidade e sertão, na qual os sertanejos sejam incorporados à pólis como cidadãos.

Há um momento em Grande sertão: veredas, em que Guimarães Rosa imagina uma outra configuração possível, estabelecida entre "civilização" e "barbárie", modernidade e tradição: trata-se do julgamento de Zé Bebelo, sinalizando o desfecho da primeira guerra do romance. O tribunal do sertão é considerado por Antonio Candido o momento no qual "o livro alcança o nível da mais alta literatura"25.

O julgamento é um momento da mais alta literatura não apenas pela narrativa bem cuidada, pelo diálogo tenso e todo ele significativo no enredo do romance. Trata-se de alta literatura porque é no julgamento que o romance rompe de modo mais decisivo com as representações cristalizadas sobre o sertão. A solução buscada pelo julgamento não tem um correspondente em outros discursos sobre o sertão. Pensemos no caso de Euclides da Cunha: como vimos, o autor de Os sertões denuncia a maneira como a urbe civilizada explora e manipula o sertão bárbaro, e conclama por uma outra relação entre os dois segmentos. Em decorrência da própria pragmática de um ensaio de cunho histórico-sociológico, a Euclides da Cunha cabia apenas interpelar os outros brasileiros da cidade para que incorporassem os sertanejos à nação,

24 RONCARI, Luiz. O Brasil de Rosa: mito e história no universo rosiano. São Paulo: Editora da Unesp, 2oo4. p. 339.

25 CANDIDO, Antonio. op. cit., p. 299. 
sugerindo assim uma mudança qualitativa na interação entre esses dois polos da sociedade brasileira. Guimarães Rosa dá um passo que só a ficção poderia lhe facultar, que é o de imaginar uma outra configuração entre civilização e barbárie. Essa configuração alternativa pode ser entrevista no julgamento de Zé Bebelo. O que procurarei mostrar e discutir aqui é que tal solução é utópica, no sentido literal da palavra: não existe em nenhum outro discurso - a não ser na transculturação imaginada de Grande sertão: veredas ${ }^{26}$. É na ficção que é proposta uma nova sociabilidade - mistura de modernidade e código de honra cavalheiresco. Um novo modo de ser no sertão.

O primeiro aspecto que devemos notar no julgamento é o seu caráter inovador e inédito naquele sistema cultural dos jagunços. Dissertando sobre os valores do homem rural brasileiro, Oliveira Vianna destaca a coragem e a defesa da honra como aqueles que estão acima de qualquer outro, e pelos quais o camponês brasileiro não mediria esforços para demonstrá-los, nem que isso fosse feito ao arrepio da lei. "O sentimento do pundonor pessoal e de coragem física, que faz com que o matuto, ferido na sua honra, desdenhe, como indigno de um homem, o desagravo dos tribunais e apele, de preferência, como nos tempos da cavalaria, para o desforco das armas"27.

Para os parâmetros dessa cultura, um julgamento não deixa de ser algo inusitado e estranho. Desnecessário acrescentar também que quem propôs a ideia do julgamento foi o próprio Zé Bebelo, pedindo que o matassem logo, pois doutro modo exigiria "julgamento correto legal" 28 . O julgamento seria já em si mesmo um procedimento moderno de lidar com as disputas - geralmente resolvidas nas infindáveis e sangrentas guerras do sertão. Contudo, a maneira como esse julgamento se dá é ainda mais surpreendente, pois outros sertanejos (outros chefes e jagunços) são interpelados a opinar, pressupondo assim uma busca por uma sentença que esteja legitimada num consenso comunitário. Joca Ramiro é a autoridade legítima daqueles bandos de jagunço, e poderia julgar o destino de Zé Bebelo apenas por suas próprias impressões, dando-lhe a sentença

26 Em Transculturación narrativa en America Latina, Angel Rama considera Guimarães Rosa um "narrador transcultural”, juntamente com Mário de Andrade, Roa Bastos, Gabriel García Márquez, por conseguir mesclar prosa de vanguarda com a matéria regional (RAMA, Angel. Transculturación narrativa en America Latina. Mexico DF: Siglo Veinteiuno editores, 1982. p. 219). A meu ver, Rosa é um narrador transcultural em mais de uma acepção, porque também imagina processos transculturais, em que diferentes sociabilidades se misturam para formar uma nova maneira de agir.

27 VIANNA, Oliveira. op. cit., p. 50. Grifos meus.

28 ROSA, João Guimarães. op. cit., p. 254. 
que avaliava como justa, sem o respaldo de ninguém. Certamente seria obedecido por todos. Joca Ramiro, no entanto, além de julgar Zé Bebelo, pretende escutar as opiniões de outros jagunços.

É importante notar que se o procedimento é moderno (julgamento) e o método de consulta é, de algum modo, democrático (buscando consenso entre os chefes e os braços d'armas), os valores para os quais a maioria converge são os da tradição sertaneja, liderados sobretudo pela fala de Titão Passos, sendo assim ressaltado um código de honra sertanejo, duríssimo e áspero na batalha, mas justo e cortês no post bellum.

Um dos pontos altos do julgamento é a própria defesa de Zé Bebelo, que, a seu próprio modo, tenta encontrar um meio-termo para a tensão entre bebelos e ramiros:

Vou depor. Vim para o Norte, pois vim, com guerra e gastos, à frente de meus homens, minha guerra... Sou crescido valente, contra homens valentes quis dar o combate... Briguei muito mediano, não obrei injustiça nem ruindades nenhumas; nunca disso me reprovam... Coisa que eu queria era proclamar outro governo, mas com a ajuda, depois, de vós também. Estou vendo que a gente só brigou por um mal-entendido, maximé. Não obedeço ordens de chefes políticos. Se eu alcançasse, entrava para política, mas pedia ao grande Joca Ramiro que encaminhasse seus brabos cabras para votarem em mim, para deputado... Ah, esse Norte em remanência: progresso forte, fartura para todos, a alegria nacional! Mas, no em mesmo, o afã da política, eu tive e não tenho mais... A gente tem de sair do sertão! Mas só se sai do sertão tomando conta dele a dentro... Agora perdi... De ter sido guardado prisioneiro vivo, e estar defronte de julgamento, isto é que louvo e que me apraz. Prova que vós nossos jagunços do Norte são civilizados de calibre: que não matam no distrair da mão um qualquer inimigo pegado. ${ }^{29}$

A fala de Zé Bebelo seria a síntese desses dois projetos ideológicos que se digladiaram no sertão, mas que estavam, por meio de tal julgamento, buscando um meio-termo para o conflito que consumia a região. Depois de se dizer independente do Governo (a civilização do litoral e sua república), Bebelo defende a proclamação de um outro governo, que não necessariamente fosse imposição da civilização do litoral ao sertão, e que teria a ajuda de pessoas como Joca Ramiro. Bebelo se alegra ao reconhecer a civilidade dos jagunços por não matarem "no distrair da

29 Idem, ibidem. op. cit., p. 276 , ênfase minha. 
mão", e entrevê neles possíveis colaboradores - caso tivesse vencido a guerra. Tudo não passou de mal-entendido, afinal, os jagunços do Norte, civilizados de calibre, não poderiam estar tão distantes de Zé Bebelo. Era necessário "sair do sertão", isto é, superar, ultrapassar, desenvolver o sertão, mas era preciso sair do sertão, "tomando conta dele a dentro". Essa frase revela a síntese que a fala de Zé Bebelo propõe para o sertão: as forças modernizadoras são necessárias para desenvolver o Norte, mas tal desenvolvimento só ocorrerá se essas forças forem incorporadas por um centro ordenador, por um "estômago antropofágico". Em outras palavras: o sertão necessita desenvolver-se organicamente, de dentro para fora, filtrando e selecionando ideias e práticas apropriadas para o seu florescimento. Uma possível síntese entre os dois vetores ideológicos, da civilização e da barbárie, que pelejaram pelo controle do sertão se dará no tribunal.

Como o tribunal do sertão pode ser interpretado? Argumento que, além de mostrar em funcionamento uma sociabilidade alternativa, ele pode ser visto como uma nova configuração da dialética entre civilização e barbárie, modernidade e tradição. E que tal configuração pode ser considerada uma resposta imaginária ao dilema colocado por Euclides da Cunha - isto é, aquela nova e híbrida sociabilidade pode ser lida como um vislumbre de uma possível civilização brasileira.

A grande dificuldade de Os sertões está em não conseguir encontrar uma solução para o abismo existente entre o Brasil litorâneo e o Brasil sertanejo. Não há dúvida, para Euclides, que o segundo Brasil é o cimento da nacionalidade, aquele que pode construir algo original e verdadeiramente brasileiro. No entanto, o mesmo isolamento que possibilitou a formação de uma raça brasileira em potencial também é o responsável pelo atraso do povo sertanejo. Caberia ao Brasil litorâneo ajudar os compatriotas atrasados a recuperarem o tempo perdido. Euclides, no entanto, é cético em relação a esse Brasil urbano e europeizado. Como afirma:

Iludidos por uma civilização de empréstimo; respingando em faina de copistas, tudo o que melhor existe nos códigos internos de outras nações, tornamos, revolucionariamente, fugindo ao transigir mais ligeiro com as exigências da nossa própria nacionalidade, mais fundo o contraste entre o nosso modo de viver e o daqueles rudes patrícios mais estrangeiros nesta terra do que os imigrantes da Europa. ${ }^{30}$

zo CUNHA, Euclides. op. cit., p. 248. Grifo meu. 
Nesse trecho, Euclides sugere que ao dar as costas às exigências "da nossa própria nacionalidade" e copiar a Europa, o Brasil litorâneo aumentava ainda mais a distância em relação aos "rudes patrícios", aqueles seriam a "rocha viva da nacionalidade". As esperanças de Euclides não estavam no Brasil urbano. Criava-se o impasse trágico da obra euclidiana: os sertanejos, apesar de formarem uma grande raça, são retrógrados e parecem não poder atingir o estágio civilizatório por eles mesmos. Os "civilizados" estão voltados para Europa e não se comprometem com as exigências da nacionalidade. Fica sugerido nesse esquema, ainda que não dito, que o Brasil só chegará à civilização por meio do desenvolvimento e da evolução orgânica do seu povo que, no entanto, não pode se desenvolver sozinho. É preciso que as elites deixem de se deslumbrar e voltem para o núcleo da nacionalidade: o povo, a cultura popular.

Ora, o que é o tribunal, senão essa mistura entre civilização e "barbárie", esse encontro entre procedimentos modernos e exaltação de valores tradicionais? E mais importante: o tribunal representa essa confluência de forças ideológicas, mas centradas no sertão, fiadas por Joca Ramiro. Para sair do sertão, afirma Zé Bebelo, é necessário sair de dentro. Grande sertão: veredas apresenta uma resposta imaginária ao dilema euclidiano, criando ficcionalmente um momento em que uma nova ponte entre Civilização e Barbárie foi feita, estabelecendo uma outra maneira de agir no sertão. Se Os sertões é um livro que denuncia a trágica situação de um país que desconhece seu próprio povo, pagando o custo de uma guerra violentíssima por essa ignorância, Grande sertão: veredas pode ser compreendido como um romance que, no momento do julgamento, ensaia na estória o diálogo que não houve na história.

\section{Transfiguração}

Diretamente associado à imaginação de um novo arranjo entre a modernidade e a tradição está o tema da transfiguração, tão caro ao pensamento de Euclides da Cunha ${ }^{31}$. Se a hipótese desse artigo estiver correta - a de que Guimarães Rosa utiliza as possibilidades oferecidas pelo discurso ficcional para radicalizar certas sugestões da obra principal de Euclides da Cunha -, o tema da transformação e metamorfose

31 Para uma discussão do tema da transfiguração em Euclides da Cunha, cf. BORGES, Dain. Euclides da Cunha's View of Brazil's Fractured Identity. In: NAVA, Carmen; LAUERHASS, Ludwig (Orgs.) Brazil in the Making: Facets of National Identity. Lanham: Rowman and Littlefield, 2006. 
seria um bom exemplo. Iniciemos a análise com um trecho de "Notas à segunda edição de Os sertões", no qual Euclides da Cunha faz a distinção entre sertanejo e jagunço.

Encontraríamos perfeito símile nessa misteriosa isomeria, mercê da qual corpos identicamente constituídos, com os mesmos átomos num arranjo semelhante, apresentam todavia propriedades diversíssimas. Assim pensando - e que se não irritem demais as sensitivas do nosso meio científico com mais esta arrancada feroz de nefelibatismo - eu vejo, e todos podem ver, no jagunco um corpo isômetro do sertanejo. ${ }^{32}$

O que está sugerido por Euclides da Cunha, nesse trecho, é que nem todo sertanejo é jagunço, embora sejam feitos do mesmo material histórico e estejam sob influência dos mesmos condicionamentos socioeconômicos, mesológicos e raciais. O que difere são as configurações que formam cada um. Na gramática euclidiana, "jagunços” são os sertanejos truculentos e bárbaros. Isso não impede que, em sua obra principal, Euclides da Cunha também vislumbre outros "isômeros" do sertanejo. Num dos momentos mais poéticos de Os sertões - pois é o momento mais imaginativo -, Euclides narra a emergência de um outro “isômero" do sertanejo, afundado em camadas de ignorância, fanatismo e superstição: o titã acobreado e potente.

O sertanejo é desgracioso, desengoçado, torto. Hércules-Quasímodo, reflete no aspecto a fealdade típica dos fracos. O andar sem firmeza, sem aprumo, quase gigante e sinuoso, aparenta a translação de membros desarticulados... É o homem permanentemente fatigado... Reflete a preguiça invencível, a atonia muscular em tudo... Entretanto, toda esta aparência de cansaço ilude... Basta o aparecimento de qualquer incidente exigindo-lhe o desencadear das energias adormecidas. O homem transfigura-se. Empertiga-se, estadeando novos relevos, novas linhas na estatura e no gesto, e a cabeça firma-se-lhe, alta, sobre os ombros possantes, aclarada pelo olhar desassombrado e forte, e corrigem-se-lhes, prestes, numa descarga nervosa instantânea, todos os efeitos do relaxamento habitual dos órgãos, e da figura vulgar do tabaréu canhestro, reponta, inesperadamente, o aspecto dominador de um

$3^{2}$ CUNHA, Euclides. op. cit., p. $5^{81}$. 
titã acobreado e potente, num desdobramento surpreendente de força e agilidade extraordinárias. ${ }^{33}$

O que se pode constatar nesse trecho é o condensamento de todas as linhas de força ideológicas de Euclides da Cunha: o vocabulário naturalista, indicando a fraqueza de uma sub-raça, o enaltecimento romântico do heroísmo sertanejo, e a metáfora classicista - o sertanejo como titã. Todo esse repertório de dicções é mobilizado para representar a transfiguração do sertanejo, e mostrar as potencialidades de uma raça cuja grandeza encontrava-se adormecida - mas que, por um ínfimo lampejo, tal grandeza poderia ser entrevista por meio de alguns gestos do sertanejo. O titã - que serve como metonímia de grandes feitos civilizatórios - é uma possibilidade do sertanejo, tal como o jagunço. Titã ou jagunço, clássico ou rústico, o sertanejo representado por Euclides da Cunha tem o potencial de percorrer todo o espectro que cobre as polaridades das representações entre civilização e barbárie. Embora o titã e o jagunço sejam formados pela mesma matéria histórica, racial e mesológica, as contingências permitem que às vezes um aflore em detrimento de outro. Em Grande sertão: veredas, Guimarães Rosa desenvolve a intuição euclidiana da isomeria na construção de mundos outros dentro do sertão. E tenta construir esses isômeros por meio da imaginação. Rosa imagina o sertão tal como se fosse composto de elementos de um caleidoscópio - que são sempre os mesmos, mas mudam constantemente de configuração também de acordo com as contingências. O que seria, por exemplo, o Tribunal do Sertão, senão um rearranjo imaginário da mistura e cumplicidade entre civilização (modernidade) e barbárie (tradição)? Seria uma nova configuração entre esses vetores ideológicos, em que uma ética da batalha emerge do polo "bárbaro", que um sentimento de honra cavalheiresca surge do polo "civilizado", enfim, uma configuração construída pela intensa reversibilidade da ficção rosiana, na qual "transtraz a esperança mesmo do meio do fel do desespero" 34 .

É importante salientar também que há uma mescla de tradição e modernidade no julgamento. Trata-se de um processo eminentemente híbrido. No seu Lembranças do Brasil, Heloísa Starling considera que o julgamento faz parte de uma série de atos fundadores malogrados, inacabados e inconclusos no romance, uma vez que, se a encenação do julgamento parece supor igualdade, a decisão última coube, como

33 Idem, ibidem, p. 105-106. Grifos meus.

34. ROSA, João Guimarães. op. cit., p. 307. 
sempre, ao chefe, Joca Ramiro ${ }^{35}$. Tal gesto, o do julgamento, inicialmente democrático, é considerado incompleto e malogrado, pois Starling estabelece como ponto de comparação a modernidade europeia. Parece ser o exato oposto que propõe a transculturação imaginada por Guimarães Rosa, uma vez que pressupõe uma negociação entre tradição e modernidade, ou, para usar a expressão euclidiana, tal transculturação pressupõe a concepção de um novo "isômero" da sociedade sertaneja. O resultado desse processo será necessariamente híbrido e impuro - se comparado aos cânones europeus.

Trata-se, portanto, de um rearranjo que é imaginado e pouco tem a ver com aquela junção narrada por Euclides, entre civilização de empréstimo e banditismo. E aqui Rosa aproveita toda a potencialidade da literatura, seguindo os preceitos da Poética de Aristóteles, na qual o poeta deve escrever sobre o que poderia ser, ao contrário do historiador que deve se ater sobre a narração do que é. Ou como diria o próprio Rosa, em Tutaméia, a "estória, a rigor, deve ser contra a História"36. É imperativo esclarecer essa frase, pois ela não sugere que a estória deva ser narrada sem levar em consideração a História, numa espécie de isolamento formalista. A História de certa maneira colabora com a estória, pois a mimese do discurso histórico ajuda a dar verossimilhança para os dilemas de um personagem, como no caso de Riobaldo. No entanto, uma vez que estabelece o cenário, é preciso sair do discurso histórico e questioná-lo, trilhando um caminho alternativo ao da história ${ }^{37}$. É desse modo que a estória deve se contrapor à História. Como afirma Robert Musil, "se há um senso de realidade, há um senso de possibilidade" 38 . A prosa de Rosa, embora alimentada por uma precisa

35 STARLING, Heloísa. Lembranças do Brasil: teoria política, história e ficção em Grande sertão: veredas. Rio de Janeiro: Revam/ UCAM/ IUPERJ, 1999. p. 91-129.

36 ROSA, João Guimarães. Tutaméia: terceiras estórias. Rio de Janeiro: Nova Fronteira, $1985 \cdot$ p. 5 .

37 A obra de Guimarães Rosa é associada a duas figuras do pensamento social brasileiro: Euclides da Cunha e Oliveira Vianna. Segundo Luiz Roncari, Rosa seguiu de perto o paradigma de Oliveira Vianna (RONCARI, Luiz. op. cit., p. 19). No decorrer deste artigo, mostramos como há uma profunda ressonância entre características da trajetória de vida de Riobaldo e o retrato da vida rural feito por Oliveira Vianna, como se Guimarães Rosa estivesse se utilizando da contextualização dada pelo autor de População meridional do Brasil para dar um certo lastro de verossimilhança sociológica aos dilemas de seus personagens. A notação social presente em Grande sertão: veredas tem forte influência de Oliveira Vianna. Por outro lado, os momentos em que essa notação social é de algum modo transcendida parecem ter a marca euclidiana.

38 MUSIL, Robert. The Man Without Qualities. London: Vintage, 1996. 
notação social, isto é, dotada de um apurado senso de realidade, investiga que virtualidades podem emergir dessa realidade.

É exatamente por entrever essas possibilidades, advindas de diferentes rearranjos das formações sociais, que a ficção de Guimarães Rosa é apropriada para pensar o híbrido, a mistura, suas propriedades e consequências. Não deixa de ser intrigante notar que boa parte da fortuna crítica de sua obra, sobretudo aquela voltada às questões mais esotéricas do universo rosiano, tenha destacado muito mais os aspectos anagógicos $^{59}$ do romance, do que aquilo que viria a ser a dimensão propriamente moderna da literatura, que é a mistura. É o mundo misturado, onde os pastos não estão demarcados, que impõe desafios para a imaginação moral do leitor: como agir num mundo de tantas incertezas éticas, onde os universais parecem seriamente abalados, onde o desejo e a norma social colidem o tempo todo, e esta última, ainda que obedecida, é constantemente questionada? Também igualmente desafiadoras são as questões que a ficção coloca em relação à contingência das formações sociais. Os diferentes arranjos ideológicos construídos no sertão tanto podem ter valor emancipatório ou utópico (como demonstrei, na resposta

39 Tanto Kathrin Rosenfield, como Francis Uteza e Benedito Nunes interpretam o texto, fazendo referência à dimensão analógica implícita no neoplatonismo, que supostamente daria suporte à visão de mundo de João Guimarães Rosa. Rosenfield vê o pacto como "redescoberta das harmonias universais" (ROSENFIELD, Kathrin H. Os descaminhos do demo: tradição e ruptura em Grande sertão: veredas. Rio de Janeiro: Imago, 1993. p. 302); Uteza vê o texto como "início de uma viagem iniciática de autoconhecimento e purificação" (UTEZA, Francis. JGR: Metafísica do Grande sertão. Trad. José Garbuglio. São Paulo: Edusp, 1994. p. 25). Em todos os casos, há uma conotação positiva, como se o pacto permitisse a Riobaldo atingir estágios mais puros e harmoniosos consigo mesmo. Minha discordância maior é no valor dado a essa autodepuração neoplatônica. O que faz de Grande sertão: veredas um romance moderno, e não um livro de autoajuda, é exatamente as complicações que o mundo misturado trazem para o autor. $\mathrm{O}$ que faz do romance universal (de interesse para o leitor contemporâneo de qualquer país) é menos a reencenação de arquétipos míticos de purificação do ser, e mais o questionamento ético de agir num mundo tão híbrido como o apresentado pelo romance. Minha discordância com Nunes já é de outra natureza. A teoria desse estudioso sobre os três amores de Rosa acaba aderindo em demasia às racionalizações do próprio Riobaldo: Nhorinhá é visto com o amor sensual, Diadorim seria o amor maligno, maldito, e Otacília, o amor sagrado, e que serve como uma espécie de Beatriz da Divina comédia. Pensando nela, o herói ultrapassaria os momentos tormentosos para chegar a searas mais tranquilas (NUNES, Benedito. O dorso do tigre: ensaios. São Paulo: Perspectiva, 1969). O modelo neoplatônico de Nunes não leva em conta o esforço hercúleo e cerebral que Riobaldo tem que fazer para se lembrar de Otacília, e que o pacto com o demoníaco afastou Riobaldo de sua ambiguidade sexual, logo do "maligno" Diadorim, e o aproximou de sua sagrada e hierática noiva, Otacília. O pacto é feito para o herói se "desmisturar", sair da zona ambivalente, que suas dúvidas sobre como agir no sertão e seu amor por Diadorim provocavam. 
imaginária dada a Euclides da Cunha por Guimarães Rosa, em que civilização e tradição sertaneja parecem entrar num acordo, esboçando uma cultura desenvolvida a partir "de dentro"), como podem exibir as facetas mais violentas e sanguinárias da sociabilidade rural, conforme demonstra o próprio Euclides da Cunha em Os sertões.

E ainda que discordemos ou achemos datados os modos como Euclides da Cunha e João Guimarães Rosa vislumbraram, cada um a seu modo, uma possível integração social da nação, o traço mais marcante de seus legados, independente da ideologia que vieram a ter, é ressaltar a plasticidade da própria ideia de integração entre diferentes partes da nação. Cabe a cada geração de leitores e cidadãos imaginar outras formas, mais justas e menos assimétricas, de diálogo e articulação entre os brasileiros. 